\title{
A Decontamination Approach Altered the Gymnanthes klotzschiana Müll. Arg. Vessel Anatomy in Southern Brazil
}

\author{
Maria R. Kanieski ${ }^{1}$, Franklin Galvão ${ }^{2}$, Paulo C. Botosso ${ }^{3}$, Philipe R. C. Soares ${ }^{1}$, Marcos F. Nicoletti ${ }^{1}$, \\ Enéas R. Konzen ${ }^{4}$, Jaçanan E. de F. Milani ${ }^{1}$, Tomaz Longhi-Santos ${ }^{2}$, Iasmin F. P. Pfutz ${ }^{2} \&$ Erika Amano $^{5}$ \\ ${ }^{1}$ Forest Engineering Department, Santa Catarina University State, Lages, Santa Catarina, Brazil \\ ${ }^{2}$ Forest Engineering Department, Federal University of Paraná, Curitiba, Paraná, Brazil \\ ${ }^{3}$ Brazilian Agricultural Research Corporation, Colombo, Paraná, Brazil \\ ${ }^{4}$ Coastal, Limnological and Marine Studies Center, Federal University of Rio Grande do Sul, Rio Grande do Sul, \\ Brazil \\ ${ }^{5}$ Botanic Department, Federal University of Paraná, Curitiba, Paraná, Brazil \\ Correspondence: Maria Raquel Kanieski, Forest Engineering Department, Santa Catarina University State, Luis \\ de Camões Avenue, 2090, 88520-000, Lages, Santa Catarina, Brazil. Tel: 55-49-3289-9305. E-mail: \\ raquel.kanieski@udesc.br
}

$\begin{array}{lcc}\text { Received: July 10,2019 } & \text { Accepted: August 24, } 2019 \quad \text { Online Published: October 15, } 2019 \\ \text { doi:10.5539/jas.v11n17p196 } & \text { URL: https://doi.org/10.5539/jas.v11n17p196 }\end{array}$

The research is financed by $C N P Q$ and $C A P E S$.

\begin{abstract}
Here we conducted an anatomical analysis of vessel elements from woody tissues of Gymnanthes klotzschiana individuals in a remnant of Alluvial Mixed Rain Forest in southern Brazil. This tree is among the species with the highest abundance within these forests. We sampled an area adjacent to a meadow highly impacted by an oil spill of four million liters from Petróleo Brasileiro S. A. The study was aimed at uncovering possible anatomical and structural changes in the wood of G. klotzschiana after an attempt at the decontamination of the area, which was performed by its flooding and extracting the oil that was deposited on the soil surface. Therefore, our sampling was performed in two environments with distinct water table characteristics: (1) with temporary water saturation, and (2) with permanent saturation. Radial samples were collected from an individual from both environments and analyzed through optical microscopy and dendroecological variables, which allowed us to reconstruct the wood development from 1997 to 2010. Our results demonstrated that no significant anatomic changes occurred in the condition with temporary saturation. Conversely, the environment with permanent saturation led to an increase in the frequency of the vessel elements, as a strategy to acclimate to the altered environment. Moreover, it altered the grouping pattern of the vessels, with a gradual increase in the percentage of solitary vessels, which is consistent with environments with more humidity. These results drive our attention for developing more efficient strategies to overcoming natural disasters and diminishing their impact on local biological communities.
\end{abstract}

Keywords: ecological anatomy, environmental pollution, vessel frequency, vessel grouping

\section{Introduction}

The variability of the wood anatomy in the growth rings depends of several environmental factors. The interpretation of such variation over the life cycle of a tree is helpful toward the development of studies within the fields of dendroecology, dendroclimatology and wood anatomy. Moreover, it is important to understand components of tree growth for species that are economically important, exotic or native to the areas they are cultivated. The information provided by such studies has the potential to indicate the quality of the wood that will produced for distinct commercial applications, such as extraction of cellulose and paper manufacture, furniture, production of charcoal. With superior quality, farmers may have much higher incomes by extracting the wood from such trees. In an alternative but complementary view, studies within the fields of dendroecology and wood anatomy have also been devoted to an ecological purpose by means of a comprehensive analysis of the 
short- and long-term effects of environmental factors to the anatomic structure of woody plants (Arnold \& Mauseth, 1999; Gärtner, Lucchinetii, \& Schweingruber, 2014; Hiendrich, Gärtner, \& Monbaron, 2007; Vaz et al., 2012).

The study of the variation of the wood anatomy is primarily concerned with the understanding of the influence of environmental factors in the structure of the xylem tissue, trying to uncover eventual strategies of plants for their survival to the distinct environments in which they gradually adapt. The size of vessels and tracheids, the cell wall thickness and its structural variation provide important information about the tree, especially when analyzed through the layers of growth (Gärtner et al., 2014; Overdieck, Zichwe, \& Böttcher-Jungclaus, 2007; Schweingruber, 2007).

The ecophisiological responses of species to environmental factors interfere with the anatomical structure, by considering the implications of the xylem to physiological processes. A comprehensive analysis of such factors allows the use of anatomical features as tools for the interpretation of ecological processes of alluvial deposits (Cosmo, Kuniyoshi, \& Botosso, 2010).

The wood vessels are among the main structures of the wood, aimed at conducting water in the majority of dicotyledons (Kedrov, 2012). They have an important role in the vulnerability to cavitation and emboly (Baas \& Wheeler, 2011). The density and diameter of the vessels are sensitive to the environment, registering differences in the growth layers in periods with high water availability in comparison to dryer periods (Verheyden, De Ridder, Schmitz, Beeckman, \& Koedam, 2005).

According to Cosmo, Kuniyoshi, and Botosso (2010), little is known about the wood anatomy of species from alluvial environments, those which have considerable environmental and socioeconomic impact. The knowledge of the anatomic variation and its dependence on the environmental variability is even more restricted.

Ecological disasters involving petroleum (oil) and derivatives are recurring issues in several areas. They are normally originated from leaking, spills or explosions which spread high amounts of the product in large areas, generating numberless negative impacts to the environment. It affects local human populations and the flora and fauna. One example of such disaster occurred in a remnant of Alluvial Mixed Rain Forest within the domains of the Refinaria Presidente Getúlio Vargas (REPAR), one of the unities of Petróleo Brasileiro S. A. (PETROBRAS), in the municipality of Araucária, PR, Brazil. In this area is located the alluvial deposit of the river Barigui. The oil spill in the area was accounted to four million liters of oil in 2000. The decontamination of the area was performed with the construction of containment dykes for flooding the nearby area. By difference of density, the oil accumulated on the surface of the soil was gradually removed. Today, the area is still maintained with a superficial water table. This might have affected the development of the wood vessels of the species that have grown in the disturbed area.

Several studies have addressed the consequences of oil spill to the plants that grow in these areas. Most of them were driven to analyze the potential of biodegradation of the contaminants by the plants (e.g., Mang Lu et al., 2010; Michel et al., 2005; Palmroth et al., 2006; White, Wolf, Thoma, \& Reynolds, 2006) and the inhibition of their germination (e.g., Gogoz, Bona, Santos, \& Botosso, 2010; Hernandez-Valencia \& Magger, 2003; Petukhov, Fomchenkov, Chugunov, \& Kholodenko, 2000; Rivera-Cruz, Ferrera-Cerrato, Volke, Rodríguez, \& Fernández, 2002). Maranho, Dziedzic, Muñiz, Kuniyoshi, and Galvão (2009) analyzed the effect of an oil spill in the size of tracheids of Podocarpus lambertii Klotzsch ex Endl., revealing differences in length and cell wall thickness of the tracheids of the individuals exposed to the pollutant. Another study showed that the contamination with oil augmented the accumulation of $\mathrm{K}$ and diminished the amounts of $\mathrm{Mg}$ and $\mathrm{Fe}$ in the biomass of Gymnanthes klotzschiana Müll. Arg. (Thibes-Rodrigues, Wisniewski, Bona, Dedecek, \& Santos, 2006). One more work with the same species provided evidence of a metabolic strategy of the species for tolerating anoxic environments by changes in the morphoanatomical structure of the plant.

The aforementioned aspects suggest that the contamination of alluvial environments with oil affects the anatomical structure of the wood. Our work was concerned with the effect of the constant water saturation of the soil in the area that was attempted the decontamination from the oil spill of Petróleo Brasileiro S.A. Therefore, we were aimed at analyzing the changes that might have occurred in the size, frequency and grouping of the vessels of G. klotzschiana after the saturation of the soil in the alluvial forest nearby the river Barigui, municipality of Araucária, PR, Brazil. 


\section{Method}

\subsection{Study Area}

This study was conducted in an area located in the municipality of Araucária, state of Paraná $\left(25^{\circ} 35^{\prime} 12^{\prime \prime}\right.$ S; $49^{\circ} 20^{\prime} 45^{\prime \prime} \mathrm{W}$ ). It consists of a floodplain area, with hydromorphic soils of type Gleysol. In 2000, an adjacent area to the one selected was compromised by an oil spill of four million liters. From the rupture point, the scraper (connects the oleoduct to the refinery) of REPAR, the oil drained through a hillside and reached the creek Saldanha, affluent of the river Barigui. Through $2.25 \mathrm{~km}$ on the course of the creek, the oil overflowed the canal, contaminating the surrounding area, reaching the river Barigui. The oil contaminated the soil, water courses and the biotic communities located nearby the scraper, reaching riparian environments close to the creek Saldanha and its extensive meadow.

Several attempts at decontaminating the area have been performed so far, including the construction of dykes and flooding of the area for capturing the oil deposited on the soil surface, due to its higher density. Nevertheless, approximately one million liters of oil remain in the meadow adjacent to the forest.

The area has a $\mathrm{Cfb}$ climate (Köppen), with the rain well distributed throughout the year, with cold winters and frequent frosts (Alvares, Stape, Sentelhas, Gonçalves, \& Sparovek, 2013). The average precipitation of the region, considering the data of the period 1961-2011 is of 1,490 mm per year, with January as the rainiest (mean of $198 \mathrm{~mm}$ ) and August with the lowest precipitation (mean of $75 \mathrm{~mm}$ ). The mean maximum temperature is of $23.4^{\circ} \mathrm{C}$, and the mean minimum temperature is of $13.0^{\circ} \mathrm{C}$. Overall, the average temperature of the area is of $18.2^{\circ} \mathrm{C}$ (Instituto Nacional de Meteorologia [INMET], 2012).

\subsection{Plant Materials and Sampling Procedures}

Two individuals of G. klotzschiana were selected, both in the same forest remnant, but in two distinct environmental conditions: (1) with hydromorphic soil (Haplic Gleysol), temporary water saturation and, more frequently, with deeper water table; (2) the same type of soil, but with permanent saturation and superficial water table.

Radial samples of the woody tissue were collected from the selected individuals (two for each individual) in a non-destructive manner with the Pressler drill, at approximately $1.3 \mathrm{~m}$ (breast height). In order to protect the injured area, it was filled with coper sulfate and calcium oxide (mixed at 1:1), which promotes tissue healing and prevents the tree from the attack from pathogens.

\subsection{Dendrochronological and Histological Analyses}

One of the samples were used for the construction of the chronological series of the tree, following dendrochronological approaches. The other sample was analyzed through microscopy. It was tangentially divided (from the cambium to the medulla) in portions of approximately $3 \mathrm{~mm}$. The samples were then immediately fixed in FAA 70 (Johansen, 1940) e placed in a vacuum desiccant for approximately 30 days. After that, the samples were dehydrated in an ethyl alcohol series, infiltrated and included in a synthetic resin (Leica Historresin ${ }^{\circledR}$ ), following manufacturer instructions. Transversal sections with approximately $4 \mu \mathrm{m}$ in thickness were obtained with a rotating microtome, placed in histological slides and stained with toluidine blue (O'brien, Feder, \& Mccully, 1965).

The anatomical analyses were performed in two individuals, after the delimitation of the growth rings, comparing the period before the contamination with the period after contamination of the two environmental conditions. The tangential diameter and the frequency of vessel elements with the application WinCell. The number of measurements was fixed in $n=30$, for each parameter evaluated, according to the recommendations of the International Association of Wood Anatomists Committee (IAWA, 1989). The grouping of the vessels was also registered, whether if they were isolated or in multiples.

\subsection{Statistical Analysis}

The data were submitted to ANOVA and further mean comparison test with Scott-Knott's $(P<0.05)$ to check for significant differences for diameter, frequency and grouping of vessels in the period before and after the oil spill (the data were grouped every three years for the statistic computations).

To compare the similarity between the anatomic characteristics of the two individuals, each in one of the distinct environmental conditions ( 1 and 2), we generated a dendrogram using the Bray-Curtis index, with the unweighted pair group method (UPGMA) of clustering. A correlation analysis between the variables was performed with the Pearson's coefficient. The normality of the data was tested with Shapiro-Wilk's $(P<0.05)$. The analyses were performed in R (R Core Team, 2017). 


\section{Results}

\subsection{Environmental Condition 1-Temporary Water Saturation}

Usually, G. klotzschiana has growth layers with radial flattening and an increased thickness of the cell wall of fibers. The porosity is diffuse, with solitary vessels, geminates or in radial groups (Cosmo, Kuniyoshi, \& Botosso, 2010). Eventually it might form semi-porous rings, although it was not observed in the present study.

The frequency of vessels per $\mathrm{mm}^{2}$ varied from 8 to 15 in the individual grown in the temporary saturation condition (Figure 1). In 2000 (as highlighted in Figure 1), when the oil spill occurred, we observed a reduced increment and an increase in the diameter and frequency of the vessel elements. The same pattern was observed in the next year.

A
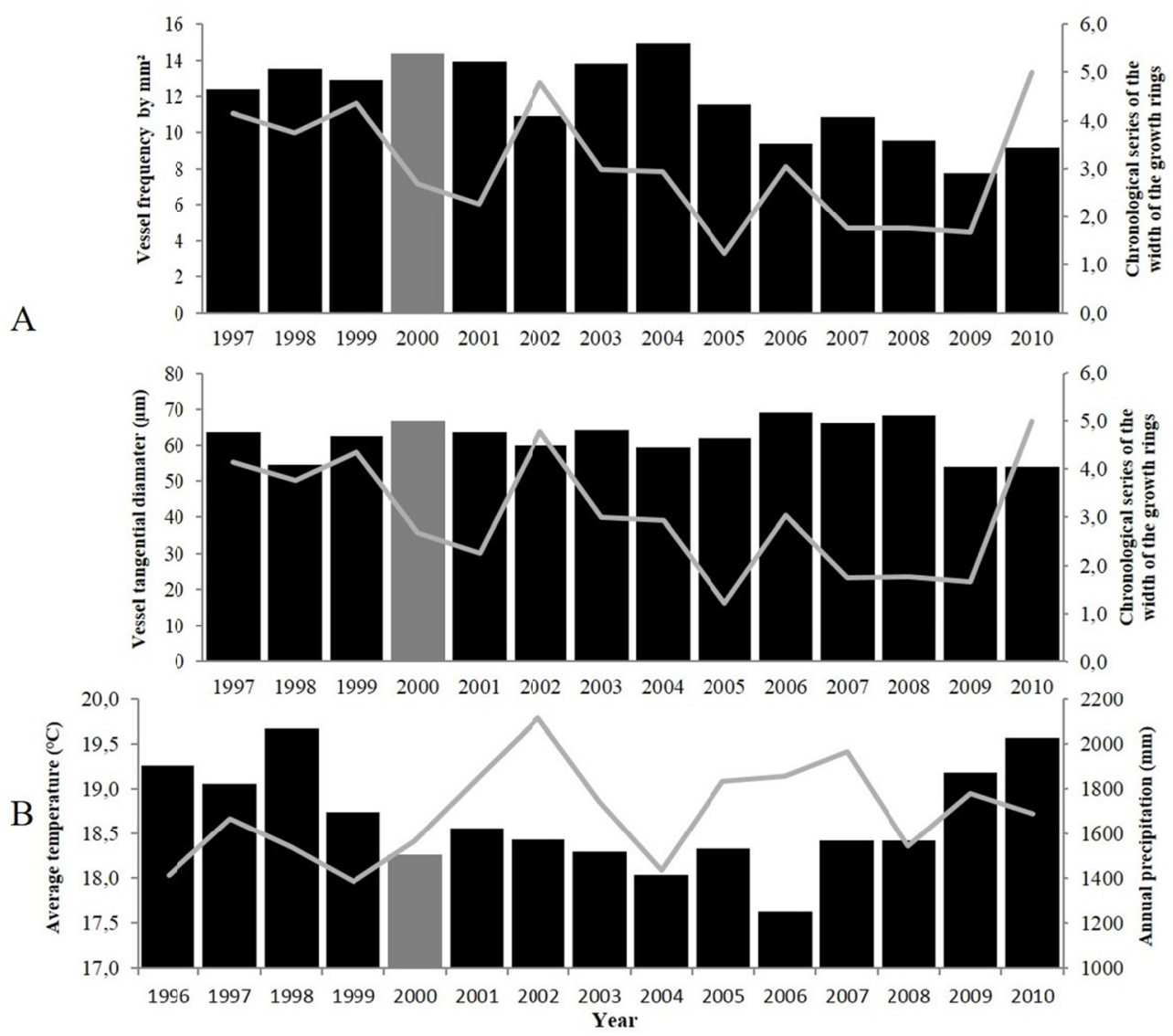

Figure 1. A. Variation in the frequency and tangential diameter of vessel elements of Gymnanthes klotzschiana, from 1997 to 2010 (bars) and chronological series of the width of the growth rings (lines) in an environment with temporary saturation. B. Precipitation (bars) and temperature (line) between 1996 and 2010

Over the years, we observed a reduction in the frequency of vessel elements. Significant differences were detected for the mean of this variable in the years prior to 2005 in comparison with the years after 2006 (Table 1). The difference in the frequency of vessels in the last years, although significant, appeared not so prominent based on a visual analysis of the layers of growth (Figure 2). 
Table 1. Mean frequency of vessel elements, diameter of vessels and proportion of multiple and solitary vessels between 1997 and 2010, with data every three years, in an area with temporary saturation (environmental condition 1)

\begin{tabular}{lllll}
\hline Period & $\begin{array}{l}\text { Frequency of vessels } \\
\left(\text { vessels } \mathrm{mm}^{-2}\right)\end{array}$ & $\begin{array}{l}\text { Diameter of vessels } \\
(\mu \mathrm{m})\end{array}$ & $\begin{array}{l}\text { Multiple vessels } \\
(\%)\end{array}$ & $\begin{array}{l}\text { Solitary vessels } \\
(\%)\end{array}$ \\
\hline $1997-1999$ & $12.95 \mathrm{a}$ & $60.18 \mathrm{a}$ & $32.15 \mathrm{a}$ & $67.85 \mathrm{a}$ \\
$2000-2002$ & $13.08 \mathrm{a}$ & $63.39 \mathrm{a}$ & $29.13 \mathrm{a}$ & $70.87 \mathrm{a}$ \\
$2003-2005$ & $13.44 \mathrm{a}$ & $61.74 \mathrm{a}$ & $32.48 \mathrm{a}$ & $67.59 \mathrm{a}$ \\
$2006-2008$ & $10.10 \mathrm{~b}$ & $67.92 \mathrm{a}$ & $33.04 \mathrm{a}$ & $66.95 \mathrm{a}$ \\
$2008-2010$ & $8.85 \mathrm{~b}$ & $58.80 \mathrm{a}$ & $31.09 \mathrm{a}$ & $68.91 \mathrm{a}$ \\
\hline
\end{tabular}

Note. Different letters represent significant difference $(P<0.05)$ according to Scott and Knott's.
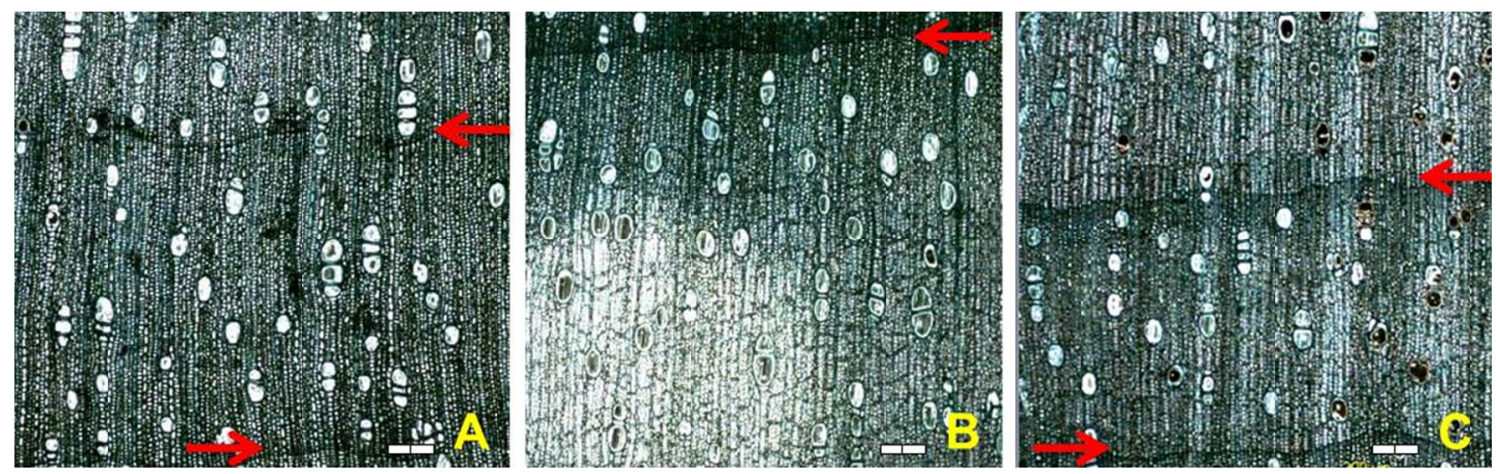

Figure 2. Transversal sections of the secondary xylem of Gymnanthes klotzschiana in an area with temporary saturation (environmental condition 1). A: layers of growth in 1998. B: layer of growth in 2000.

C: Layer of growth in 2006

Note. The arrows indicate the limits of the growth layers. Bars represent $200 \mu \mathrm{m}$.

The mean tangential diameter of the vessel elements (Figure 1) varied from 53.9 to $74.6 \mu \mathrm{m}$, but no significant difference was detected among the diameters over the years (Table 1). The grouping of the vessels and the proportion of multiple and solitary vessels were similar in the period evaluated, with no significant differences (Table 1). The solitary vessels, though, prevailed (Figure 3). The correlation analysis between the year and the frequency of vessels revealed a strong negative coefficient (Figure 4).

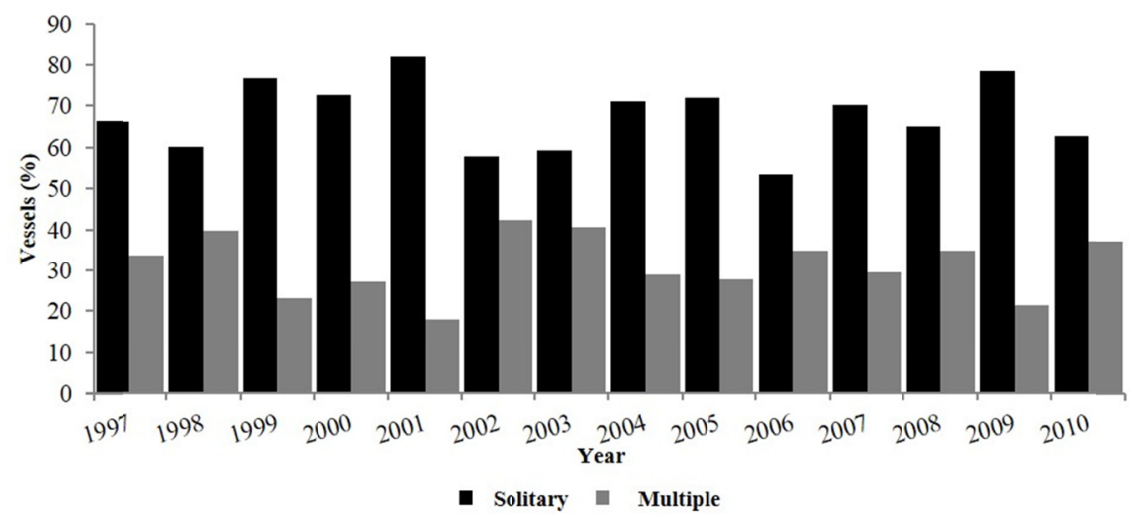

Figure 3. Variation in grouping of vessel elements of Gymnanthes klotzschiana, from 1997 to 2010, in na environment with temporary saturation (condition 1) 


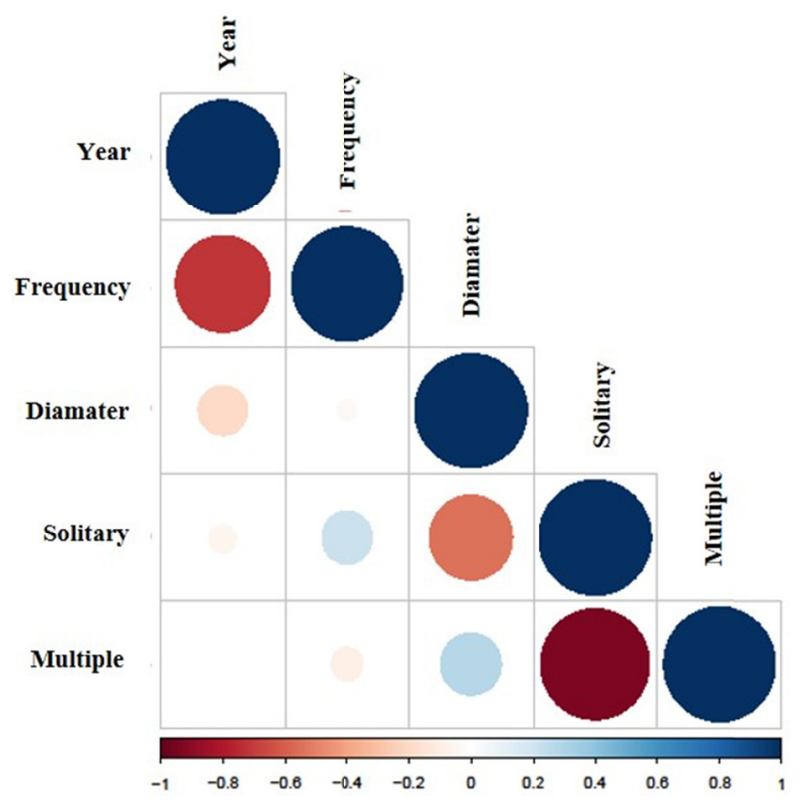

Figure 4. Correlation among the variables evaluated for Gymnanthes klotzschiana in na environment with temporary saturation (condition 1)

The clustering analysis with UPGMA for the environmental condition 1 revealed three distinct groups (Figure 5). The first encompassed the growth period of years before and after the oil spill. The second group included the years 2001 and 2009. The third group was composed by the years after the oil spill, with the exception of the year of the oil spill itself 2000 and 1999.

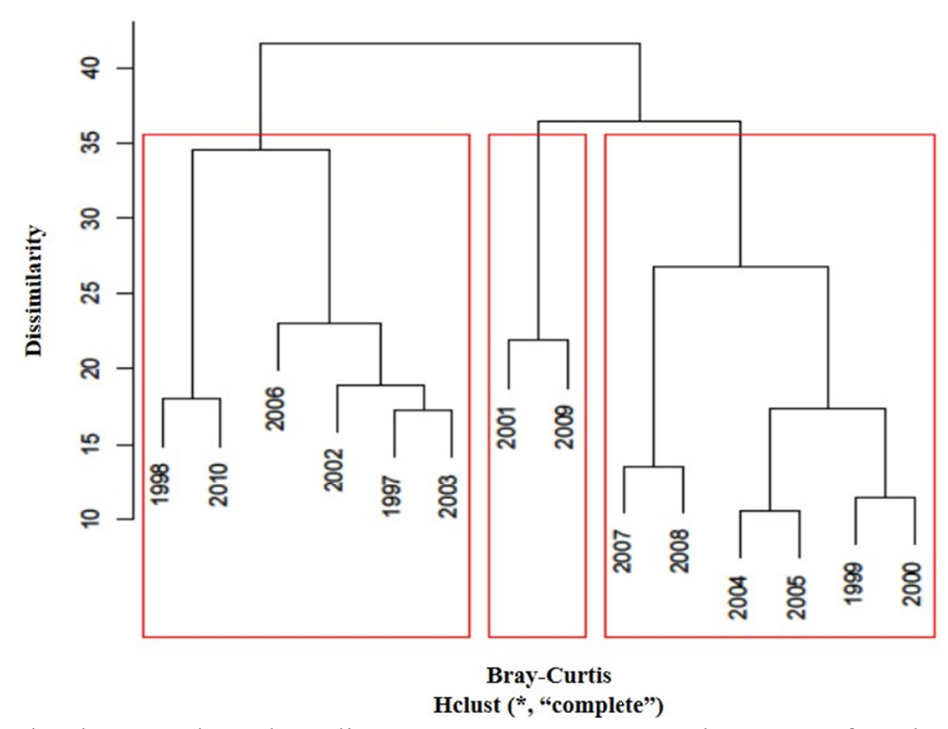

Figure 5. UPGMA dendrogram based on distance measures among the years of evaluation of Gymnanthes klotzschiana in an environment with temporary saturation (condition 1)

\subsection{Second Environmental Condition-Permanent Water Saturation}

In the second individual, grown in the environment with permanent saturation, the frequency of vessels varied from 11 to 22 vessels $\mathrm{mm}^{-2}$. The lowest value was found in the year before the oil spill, and the highest in 2010 (Figure 6). 

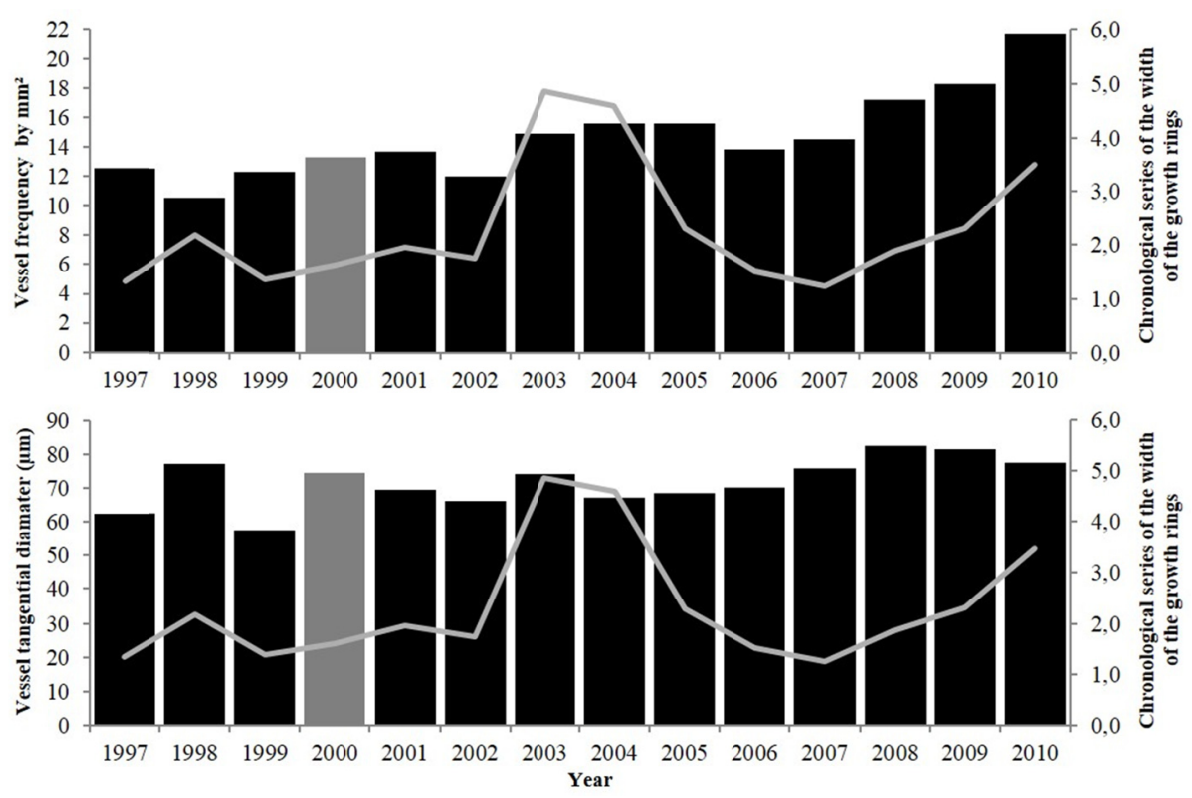

Figure 6. Variation in the frequency and tangential diameter of vessel elements of Gymnanthes klotzschiana, from 1997 to 2010 (bars) and chronological series of the width of the growth rings (lines) in the environmental condition 2, with permanent saturation

A significant difference of the frequency of vessels was encountered between the years before 2000 and the years after 2003 (Table 2). It indicates that the change in pattern was not immediate after the area was flooded. The species showed a gradual response to the new environmental condition, as shown in Figure 7.

Table 2. Mean frequency of vessel elements, diameter of vessels and proportion of multiple and solitary vessels between 1997 and 2010, with data every three years, in an area with permanent saturation (environmental condition 2)

\begin{tabular}{lllll}
\hline Period & $\begin{array}{l}\text { Frequency of vessels } \\
(\text { vessels mm }\end{array}$ & $\begin{array}{l}\text { Diameter of vessels } \\
(\mu \mathrm{m})\end{array}$ & $\begin{array}{l}\text { Multiple vessels } \\
(\%)\end{array}$ & $\begin{array}{l}\text { Solitary vessels } \\
(\%)\end{array}$ \\
\hline $1997-1999$ & $11.84 \mathrm{a}$ & $53.71 \mathrm{a}$ & $42.56 \mathrm{~b}$ & $58.62 \mathrm{a}$ \\
$2000-2002$ & $13.02 \mathrm{a}$ & $56.67 \mathrm{a}$ & $38.88 \mathrm{~b}$ & $61.21 \mathrm{a}$ \\
$2003-2005$ & $15.42 \mathrm{~b}$ & $55.77 \mathrm{a}$ & $28.66 \mathrm{a}$ & $71.34 \mathrm{a}$ \\
$2006-2008$ & $15.22 \mathrm{~b}$ & $63.26 \mathrm{~b}$ & $30.98 \mathrm{a}$ & $69.02 \mathrm{a}$ \\
$2008-2010$ & $19.09 \mathrm{c}$ & $65.84 \mathrm{~b}$ & $24.74 \mathrm{a}$ & $75.26 \mathrm{a}$
\end{tabular}

Note. Different letters represent significant difference $(P<0.05)$ according to Scott and Knott's. 

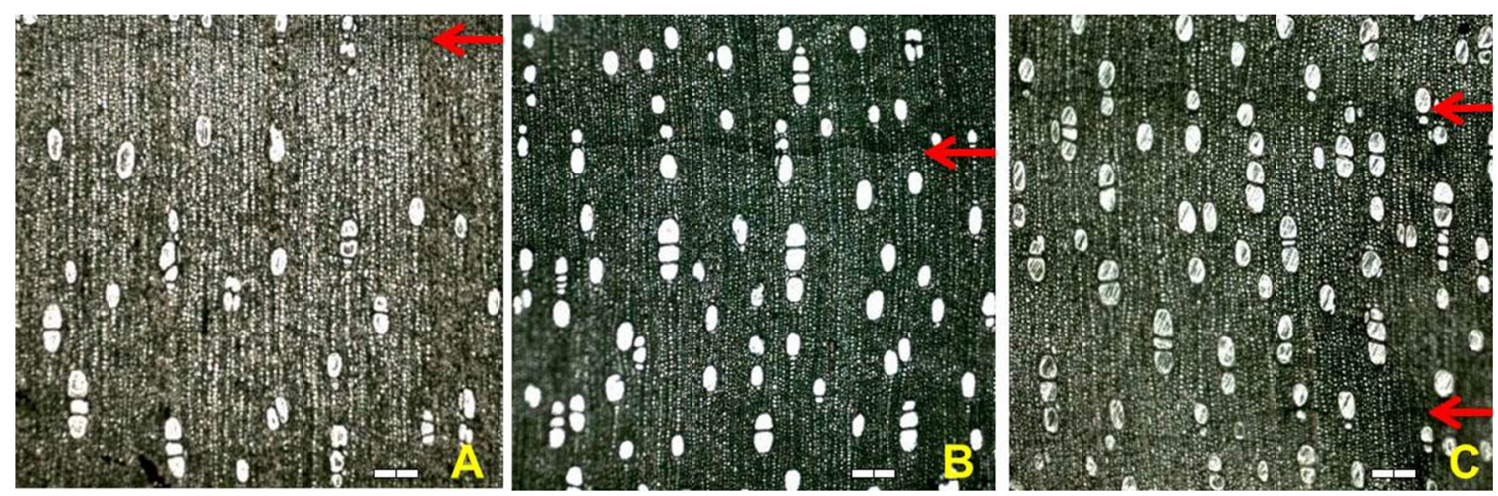

Figure 7. Secondary xylem of Gymnanthes klotzschiana in a transversal section in an area with permanent saturation (environmental condition 2). A: growth layer of 1997. B: Growth layers of 2003.

C: Growth layer of 2009

Note. The arrows indicate the limits of the growth layer. Bars represent $200 \mu \mathrm{m}$.

The mean diameter of the vessel elements varied from 57.4 to $82.2 \mu \mathrm{m}$. The lowest value was found before 2000 . A significant difference was detected between the diameters in the years after 2006 in comparison with the years before 2005 (Table 2). The grouping of the vessels was also altered. The number of multiple vessels was diminished after 2000 (Figure 8), showing a significant difference (Table 2).

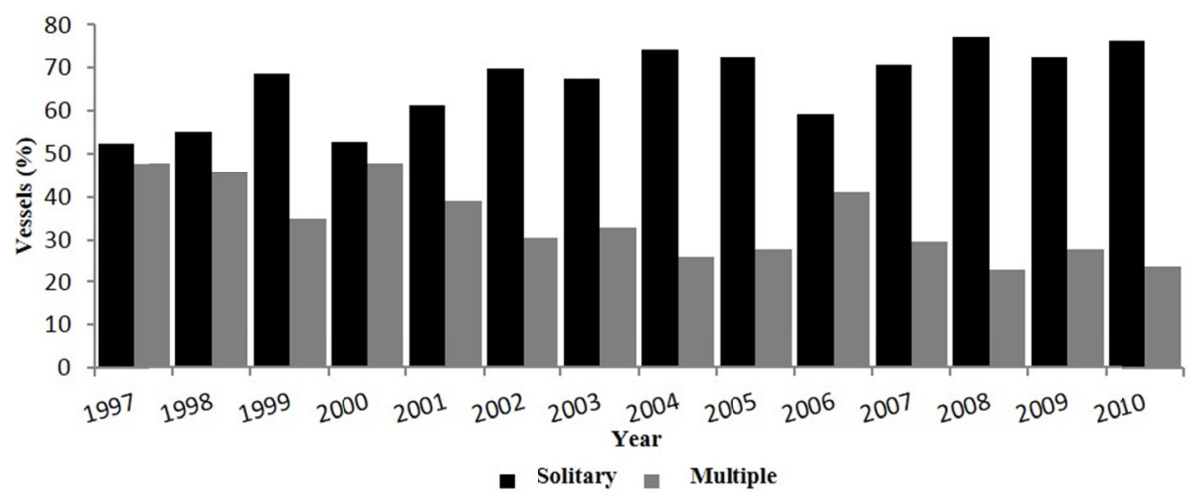

Figure 8. Variation in grouping of vessel elements of Gymnanthes klotzschiana in an area with permanent saturation (environmental condition 2), from 1997 to 2010

The correlation analysis showed a higher correlation among the variables, positive or negative, in the environmental condition 2 (permanently saturated after the oil spill), in comparison with the condition 1 . In the environment 2 (Figure 9), a high positive correlation between the year and the frequency of vessel elements was detected. A high correlation was also detected between the year and the diameter of the vessels and if they were solitary. A high negative correlation was also detected with the presence of multiple vessels. 


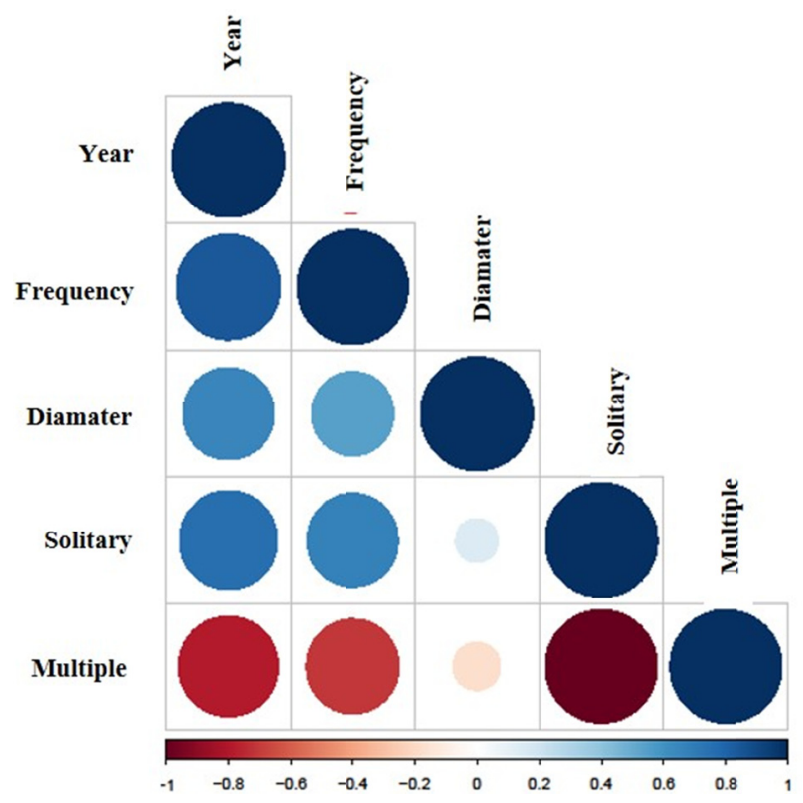

Figure 9. Correlation among the variables evaluated for Gymnanthes klotzschiana in na environment with permanent saturation (condition 2)

The clustering analysis for the environment 2 (Figure 10) also divided three distinct groups. The first was formed only by the growth period after the oil spill. The second group was majorly composed by the growth period after the oil spill, with the exception of the year 1999. The third group included, mostly, the years after the oil spill, but also 1997, 1998 and 2000 (the year of the oil spill).

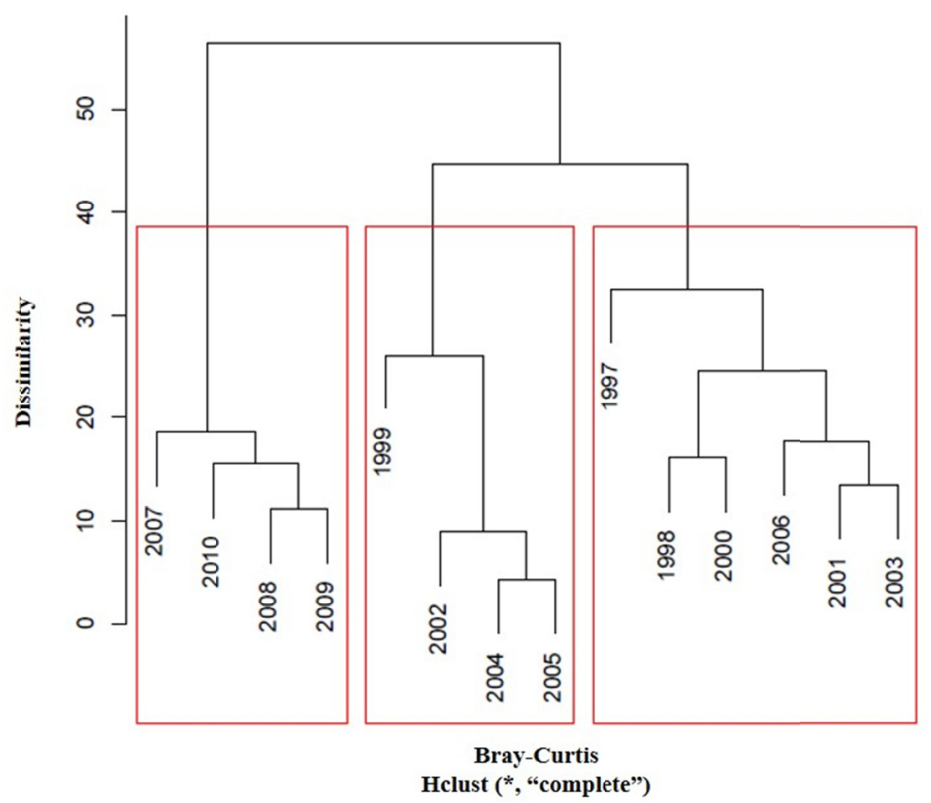

Figure 10. UPGMA dendrogram based on distance measures among the years of evaluation of Gymnanthes klotzschiana in an environment with temporary saturation (condition 2)

\section{Discussion}

Our work was driven to uncovering the changes in the frequency and size of vessel elements in individuals of $G$. klotzschiana located in two environmental conditions, after a natural disaster originated from an oil spill in southern Brazil. In general, the two environments showed opposite trends into what concerns the frequency of 
the vessel elements after the oil spill. An initial increase in the frequency of vessel elements was observed at first in the environment with temporary saturation right after the oil spill (environment 1), followed by a gradual decrease over the next years. On the contrary, an overall increase in their frequency was accounted in the ten years following the oil spill in the environment with permanent saturation (environment 2).

\subsection{Environment 1-Temporary Water Saturation}

The increase in the frequency and diameter of the vessel elements after the oil spill might be a mechanism of the plant for circumventing the stress caused by the pollutant, as it probably obstructed vessels and diminished the capacity of conducting water by the individual. In 2002, the individual showed an increase in the growth rhythm, pulsed by higher temperatures. Meanwhile, the frequency and diameter of the vessels were reduced in this year, probably because the oil no longer promoted significance influence after the area started to be recovered. These results are confirmed by the high negative correlation coefficient between the year and the frequency of the vessels, meaning that, over the years after the oil spill, the frequency of vessel elements was reduced.

The reduction in frequency of the vessels in 2006 might be a result of the low precipitation of the period, which probably leads the plant to respond to a condition with limited water availability. Then, the tree would probably not be highly efficient in conducting water, as an augmented frequency in vessels generally increases the efficiency in conducting water, because there are more ways by which water can be conducted (Bass \& Wheeler, 2011). Also, in this environment, as no distinct conditions occurred, related to the soil moisture after the contamination, also no variation was implicated in the tangential diameter of the vessels.

After categorizing the vessel elements, we observed that most of them were solitary. Multiple vessels were observed in much lower numbers. Multiple vessels are characteristics of species that are under water deficit (Baas, Werker, \& Fahn, 1983; Carlquist, 2001; Kedrov, 2012; Zimmermann, 1983), which does not fit the conditions of the study area. On the contrary, the high number of solitary vessels observed is consistent with environments with higher humidity (Alves \& Angyalossy-Alfonso, 2000).

The clustering analysis showed no clear distinction among the years accounted for collecting the data. Despite that, the second and third group are majorly composed by the years after the oil spill, except the year of the spill and 1999.

\subsection{Environment 2-Permanent Saturation}

Contrary to the previous environment, the permanent saturation condition led to an increase in the frequency of the vessels over the years after the oil spill. The frequency values in this environment were also higher than in environment 1, especially after the contamination of the area. In 1998, which showed the lowest frequency of vessels, high amounts of precipitation were accumulated, year in which one of the highest tangential diameters were observed. Therefore, for increasing the efficiency in conducting water, the tree increased the diameter of the vessels but not their frequency. In 2000 and 2001, as a result of the oil spill, the individual augment both the frequency and the diameter of the vessels, in benefit of a better water conductance. In 2003 and 2004, years when the individual presented the highest rates of growth, higher frequency and tangential diameter of the vessels were observed.

Our results demonstrated that the flooding after the oil spill has certainly stimulated anatomical changes in the wood. For being more efficient in water conduction, and with more water available, the frequency of vessels was increased. Probably if the area were not disturbed, similar pattern to individual 1 would have been observed. This is corroborated with the correlation among the variables, in which a high and positive correlation between the year and the frequency of vessels was detected, showing an increase in the frequency of the vessels in the years following the oil spill. This is similar to what was observed with the length and diameter of the vessel elements and whether they were arranged as solitary. Moreover, there was high negative correlation with the presence of multiple vessels, especially multiples of two, having those diminished after the oil spill.

Our results are compatible with Cosmo, Kuniyoshi, and Botosso (2010), that observed the lowest mean vessel frequencies for G. klotzschiana in the areas with lower water availability (Psammitic Deposit), when compare to areas with more water (Fluvic Neosoils and Melanic Gleysol). The same author argues that the opposite could be expected, as the trees might be under drought stress and then a higher number of vessel could be strategic for tolerating the condition.

The increase in diameter of the vessels, although low, as also observed by Cosmo, Kuniyoshi, and Botosso (2010), is important in the conductance of water. Zimmermmann (1983) described that the conductance is proportional to the fourth power of the radium of the vessels. Cosmo, Kuniyoshi, and Botosso (2010) 
encountered higher diameters in the wettest area (Fluvic Neosol), arguing that the species probably develops a more efficient system for water conductance in this condition.

According to Bass and Wheeler (2011), larger vessels have high efficiency in water conductance, while the opposite is also true for smaller vessels. In this case, the increase in the tangential diameter was not so prominent than the increase in the frequency of the vessels. The low efficiency in water conductance ends up compensated with the production of a high number of smaller vessels, augmenting the potential for conducting water and diminishing the risks to embolism (Bass \& Weeler, 2011).

A higher number of multiple vessels allows more ways for the water passage, being an important characteristic in species prone to water deficit (Baas et al., 1983; Carlquist, 2001; Kedrov, 2012; Zimmermann, 1983). Similarly, solitary vessels are more frequent in humid environments and rarely appear as groups (Alves \& Angyalossy-Alfonso, 2000). Our results are then consistent with the increased water availability in the areas after the oil spill. In the case of the environment 1, the proportions between solitary and multiple vessels was practically not altered over the years, which is justified by the little change in water availability to this environment.

By performing a comparison between the individuals of G. klotzchiana in the two environments, we clearly observed anatomical changes in the individual located in the condition with permanent saturation, as a change imposed by the new environmental setup. This indicates that $G$. klotzchiana is responsive to distinct environments. Similar trend was observed with species of Euphorbiaceae located in an Alluvial Dense Rain Forest located in Rio de Janeiro, also compared between an environment with permanent saturation and another with temporary saturation (Callado, Silva Neto, Scarano, Barros, \& Costa, 2001). The aforementioned work of Cosmo, Kuniyoshi, and Botosso (2010) reached similar results as well. The ability to acclimate to such new environment is a distinctive aspect of the species, which allows its survival in altered environments, such as those polluted with an oil spill. Over the generations, such acclimation along with genetic mechanisms of the local population of that species might even lead to an adaptation to such adversities.

Beyond oil spills, the repercussions of other pollutants on anatomic aspects of plants have also been studied, such the effects of gases $\left(\mathrm{CO}_{2}\right.$ and $\left.\mathrm{O}_{3}\right)$ and heavy metals. Kim, Labbé, Warren, Elder, and Rials (2015) studied the changes in the anatomic structure of Liquidambar styraciflua L. under exposition to elevated $\mathrm{CO}_{2}$ concentrations over 11 years. In the conditions of pollution, the xylem cells presented higher diameter, with a thinner cell wall. Kostiainen, Sarampää, Lundqvist, Kubiske, and Vapaavuori (2014) also encountered less vessel elements, but with higher diameter, in Populus tremuloides Michx. and Betula papyrifera Marsh. under high $\mathrm{CO}_{2}$ concentrations. These authors, however, observed the presence of vessels with lower diameter under elevated concentrations of $\mathrm{O}_{3}$. It must be highlighted, though, that the response of the species to increased $\mathrm{CO}_{2}$ relies upon the sensitivity of the species itself. This was an observation of Watanabe, Satomura, Sasa, Funada, and Koike (2010), which worked with four species, but with three of them (Quercus mongolica Fisch. Ex Ledeb, Acer mono Maxim. and Betula maximowicziana Regel) no significant variation in the vessel anatomy was observed as the $\mathrm{CO}_{2}$ concentration raised. Into what concerns heavy metals, Gomes et al. (2011) evaluated the behavior of the wood anatomy of young plants of Salix humboldtiana Willd. in soil contaminated with heavy metals originated from residues of zinc mining industry. In soils with higher contamination, plants produced lower dry matter and had less xylem cells.

The clustering analysis of the environment 2 also showed three distinct groups. The first was only composed by the growth period after the oil spill, specifically the last four years. In the chronological series of the growth rings, the last four years showed that the tree gradually started to increase the growth rhythm, after years with reduced growth. The second and third group include mostly the years with slower growth rhythm, especially after the oil spill, except for 2003 and 2004, those with more accelerated growth.

\section{Conclusions}

Our data revealed that individuals of G. klotzschiana under temporary water saturation, in general, showed no significant changes in the frequency of vessel elements and their size over the years after the oil spill. Their responsiveness was majorly attributed to meteorological conditions.

In the second environment, with permanent saturation, we clearly observed anatomical differences in $G$. klotzschiana, mainly in the frequency and grouping of the vessel elements, as a strategy to acclimate to newly formed conditions in that environment. This suggests that the species is responsive to altered environmental conditions, as anatomical changes were observed. 
The strategies used to overcome the oil spill, by flooding the area and extracting the oil, lead to considerable changes in the anatomical behavior of G. klotzschiana. Although the species might have shown acclimation mechanisms to such situation and even could adapt to the newly imposed condition over the generations, these results drive our attention to the need of developing more efficient strategies for overcoming such natural disasters and diminishing its impacts to local biological communities.

\section{Acknowledgements}

We acknowleged to REPAR, for the infrastructure and the possibility of carrying out the study in its premises; to INMET, for the availability of meteorological data and to CNPQ and CAPES for financial resources.

\section{References}

Alvares, C. A., Stape, J. L., Sentelhas, P. C., Gonçalves, J. L. M., \& Sparovek, G. (2013). Köppen's climate classification map for Brazil. Meteorologische Zeitschrift, 22(6), 711-728. https://doi.org/10.1127/ 0941-2948/2013/0507

Alves, E. S., \& Angyalossy-Alfonso, V. (2000). Ecological trends in the wood anatomy of some brazilian species. 1. Growth rings and vessels. IAWA Journal, 21, 3-30. https://doi.org/10.1163/22941932-90000233

Arnold, D. H., \& Mauseth, J. D. (1999). Effects of environmental factors on development of wood. American Journal of Botany, 86, 367-371. https://doi.org/10.2307/2656758

Baas, P., \& Wheeler, E. A. (2011). Wood anatomy and climate change. In T. R. Hodkinson, M. B. Jones, S. Waldren, \& J. A. N. Parnell (Eds.), Climate Change, Ecology and Systematics (pp. 141-155). Cambridge: Cambridge University Press. https://doi.org/10.1017/CBO9780511974540.007

Baas, P., Werker, E., \& Fahn, A. (1983). Some ecological trends in vessel characters. IAWA Bulletin, 4, 2-3. https://doi.org/10.1163/22941932-90000407

Callado, C. H., Silva Neto, S. J., Scarano, F. R., Barros, C. F., \& Costa, C. G. (2001). Anatomical features of growth rings in flood-prone trees of the Atlantic Rain Forest in Rio de Janeiro, Brazil. IAWA Journal, 22, 29-42. https://doi.org/10.1163/22941932-90000266

Carlquist, S. (2001). Comparative wood anatomy: Systematic, ecological, and evolutionary aspects of dicotyledon wood. New York, NY: Spring-Verlag. https://doi.org/10.1163/22941932-90001100

Cosmo, N. L., Kuniyoshi, Y. S., \& Botosso, P. C. (2010). Wood anatomy of Sebastiania commersoniana (Baillon) Smith \& Downs (Euphorbiaceae): functional and ecological aspects. Acta Botanica Brasílica, 24, 747-755. https://doi.org/10.1590/S0102-33062010000300018

Gärtner, H., Lucchinetti, S., \& Schweingruber, F. H. (2014). New perspectives for wood anatomical analysis in Dendrosciences: The GSL1-microtome. Dendrochronologia, 32, 47-51. https://doi.org/10.1016/j.dendro. 2013.07.002

Gogosz, A. M., Bona, C., Santos, G. O., \& Botosso, P. C. (2010). Germination and initial growth of Campomanesia xanthocarpa O. Berg. (Myrtaceae), in petroleum-contaminated soil and bioremediated soil. Brazilian Journal of Biology, 70(4), 977-986. https://doi.org/10.1590/S1519-69842010000500009

Gomes, M. P., Marques, T. C. L. L. S. M., Nogueira, M. O. G., Silva, G. H., Castro, E. M., \& Soares, A. M. (2011). Effects of tailings from zinc industry in the anatomy and growth of young plants of Salix humboldtiana Willd. (willow). Hoehnea, 38(1), 135-142. https://doi.org/10.1590/S2236-89062011000 100012

Hernandez-Valencia, I., \& Magger, D. (2003). Use of Panicum maximum and Brachiaria brizantha to phytoremediate polluted soils with light crude oil. Bioagro, 15(3), 149-155.

Hiendrich, I., Gärtner, H., \& Monbaron, M. (2007). Tension wood formed in Fagus sylvatica and Alnus glutinosa after simulated mass movement events. IAWA Journal, 28, 39-48. https://doi.org/10.1163/2294193290001617

IAWA Committee. (1989). IAWA list of microscopic features for hardwood identification. IAWA Journal, 10, 219-332. https://doi.org/10.1163/22941932-90000496

INMET (Instituto Nacional de Meteorologia). (2012). Weather database for teaching and research. Retrieved from http://www.inmet.gov.br/portal/index.php?r=bdmep/bdmep

Johansen, D. A. (1940). Plant microtechnique. New York, NY: Mc Graw Hill Book.

Kedrov, G. B. (2012). Functioning Wood. Wulfenia Journal, 19, 57-95. 
Kim, K., Labbé, N., Warren, J. M., Elder, T., \& Rials, T. G. (2015). Chemical and anatomical changes in Liquidambar styraciflua L. xylem after long term exposure to elevated $\mathrm{CO}_{2}$. Environmental Pollution, 198, 179-185. https://doi.org/10.1016/j.envpol.2015.01.006

Kostiainen, K., Sarampää, P., Lundqvist, S. O., Kubiske, M. E., \& Vapaavuori, E. (2014). Wood properties of Populus and Betula in long-term exposure to elevated $\mathrm{CO}_{2}$ and $\mathrm{O}_{3}$. Plant, Cell and Environment, 37, 1452-1463. https://doi.org/10.1111/pce.12261

Mang, L., Zhongzhi, Z., Shanshan, S., Xiaofang, W., Qinfang, W., \& Youming, S. (2010). The Use of Goosegrass (Eleusine indica) to Remediate Soil Contaminated with Petroleum. Water Air Soil Pollution, 209, 181-189. https://doi.org/10.1007/s11270-009-0190-x

Maranho, L. T., Dziedzic, M., Muñiz, G. I. B., Kuniyoshi, Y. S., \& Galvão, F. (2009). Effects of the pollution by petroleum on the tracheids along the stem of Podocarpus lambertii Klotzsch ex Endl., Podocarpaceae. Brazilian Journal of Biology, 69(2), 263-269. https://doi.org/10.1590/S1519-69842009000200005

Michel, J., Trevor, G., Waldron, J., Blocksisidge, C. T., Etkin, D. S., \& Urban, R. (2005). Potentially polluting wrecks in marine waters. Annals of the 2005 International Oil Spill Conference (pp. 1-84). Miami, USA: Oil Spill Response.

O’brien, T. P., Feder, N., \& Mccully, M. E. (1965). Polychromatic staining of plant cell walls by toluidine blue O. Protoplasma, 59, 368-373. https://doi.org/10.1007/BF01248568

Overdieck, D., Zichwe, D., \& Böttcher-Jungclaus, K. (2007). Temperature responses of growth and wood anatomy in European beech saplings grown in different carbon dioxide concentrations. Tree Physiology, 27, 261-268. https://doi.org/10.1093/treephys/27.2.261

Palmroth, M. R. T., Koskinen, P. E. P., Pichtel, J., Vaajasaari, K., Joutti, A., Tuhkanen, T. A., \& Punakka, J. A. (2006). Field-scale assessment of phytotreatment of soil contaminated with weathered hydrocarbons and heavy metals. Journal of Soils and Sediments, 6, 128-136. https://doi.org/10.1065/jss2006.07.170

Petukhov, V. N., Fomchenkov, V. M., Chugunov, V. A., \& Kholodenko, V. P. (2000). Plant biotests of soil and water, polluted with petroleum and petroleum products. Applied and Environmental Microbiology, 36(6), 652-655.

R Core Team. (2017). R: A language and environment for statistical computing. Vienna, Austria: R Foundation for Statistical Computing. Retrieved from https://www.R-project.org

Rivera-Cruz, M. C., Ferrera-Cerrato, R., Volke, H. V., Rodríguez, V. R., \& Fernández, L. L. (2002). Microbial populations in soil profiles affected by oil hydrocarbons at Tabasco State, México. Agrociencia, 36(2), 149-160.

Schweingruber, F. H. (2007). Wood structure and environment. Heidelberg, Germany: Springer Series in Wood Science. https://doi.org/10.1007/978-3-540-48548-3

Thibes-Rodrigues, T., Wisniewski, C., Bona, C., Dedecek, R. A., \& Santos, G. O. (2006). Nutritional status of Sebastiania commersoniana (Baillon) Smith \& Downs - Euphorbiaceae growing on soil contaminated with petroleum. Floresta, 36(3), 349-358. https://doi.org/10.5380/rf.v36i3.7514

Vaz, M., Cochard, H., Gazarini, L., Graça, J., Chaves, M. M., \& Pereira, J. S. (2012). Cork oak (Quercus suber L.) seedlings acclimate to elevated $\mathrm{CO} 2$ and water stress: Photosynthesis, growth, wood anatomy and hydraulic conductivity. Trees, 26, 1145-1157. https://doi.org/10.1007/s00468-012-0707-6

Verheyden, A., De Ridder, F., Schmitz, N., Beeckman, H., \& Koedam, N. (2005). High-resolution time series of vessel density in Kenyan mangrove trees reveal a link with climate. New Phytologist, 167, 425-435. https://doi.org/0.1111/j.1469-8137.2005.01415.x

Watanabe, Y., Satomura, T., Sasa, K., Funada, R., \& Koike, T. (2010). Differential anatomical responses to elevate $\mathrm{CO}_{2}$ in saplings of four hardwood species. Plant, Cell and Environment, 33, 1101-1111. https://doi.org/10.1111/j.1365-3040.2010.02132.x

White, P. M., Wolf, D. C., Thoma, G. J., \& Reynolds, C. M. (2006). Phytoremediation of alkylated polycyclic aromatic hydrocarbons in a crude oil-contaminated soil. Water, Air, and Soil Pollution, 169, $207-220$. https://doi.org/10.1007/s11270-006-2194-0

Zimmermann, M. H. (1983). Xylem structure and the ascent of sap. Berlin, Germany: Springer Series in Wood Science. https://doi.org/10.1086/414097 


\section{Copyrights}

Copyright for this article is retained by the author(s), with first publication rights granted to the journal.

This is an open-access article distributed under the terms and conditions of the Creative Commons Attribution license (http://creativecommons.org/licenses/by/4.0/). 